\title{
AKTIVITAS SENYAWA ANTIBAKTERI DAN ANTI-UV DARI Phyllidia varicosa (Cuvier, 1804) DAN BAKTERI SIMBIONNYA (NUDIBRANCHIA GASTROPODA) DARI PERAIRAN TANJUNG MANDOLANG, MINAHASA
}

(Activity Of Antibacterial And Anti-UV Compounds From Phyllidia varicosa (Cuvier, 1804) And The Symbiont (Nudibranchia Gastropoda) From Tanjung Mandolang, Minahasa)

Melania Ukar ${ }^{1}$, Robert A. Bara ${ }^{{ }^{*}}$, Veibe Warouw ${ }^{1}$, Inneke F. M. Rumengan ${ }^{1}$, Losung Fitje $^{1}$, Meiske Salaki ${ }^{2}$

${ }^{1}$ Program Studi IImu Kelautan, FPIK Unsrat Manado

${ }^{2}$ Program Studi Manajemen Sumber Daya Perairan FPIK Unsrat Manado

*e-mail : robert.bara@unsrat.ac.id

\begin{abstract}
Phyllidia varicosa is an organism belongsto the order Nudibranchia, which is commonly known as a sea rabbit. This organism is able to synthesize secondary metabolites from food. The purpose of this study was to obtain $P$. varicosa extract and symbiotic bacterial extract from $P$. varicosa, then determine the antibacterial activity of $P$. varicosa extract and the symbionic bacteria extract against Escherichia coli DSM498, Bacillus megaterium DSM32T and anti-UV activity. $P$. varicose symbiotic bacterial were isolated and extracted. The results obtained 5 bacterial isolates. The results of antibacterial assay of isolates PhVa 1.1, PhVa 1.3, PhVa 2.1, PhVa 2.3 and PhVa 2.4 shown that these isolates have an antibacterial activity against $E$. coli DSM498 and B. megaterium DSM32T. Anti-UV assay results shown an absorption at UV-A with the highest value of 1.991 at $\lambda 340 \mathrm{~nm}$.
\end{abstract}

Keywords: Nudibranchia, Phyllidia varicosa, Antibacterial, Anti-UV, Escherichia coli, Bacillus megaterium

\begin{abstract}
Abstrak
Phyllidia varicosa merupakan organisme yang termasuk dalam ordo Nudibranchia, yang umumnya dikenal sebagai kelinci laut. Organisme ini mampu mensintesis metabolit sekunder dari bahan makanannya. Tujuan dari penelitian ini yaitu untuk mendapatkan ekstrak $P$. varicosa dan ekstrak bakteri simbion dari $P$. varicosa, kemudian mengamati aktivitas antibakteri dari ekstrak $P$. varicosa dan ekstrak bakteri simbionnya terhadap bakteri Escherichia coli DSM498 dan Bacillus megaterium DSM $32^{\top}$ serta menguji aktivitas anti-UV. Bakteri yang bersimbion dengan $P$. varicosa diisolasi dan diekstraksi, lalu diuji bioaktivitas antibakteri dan diuji anti-UV terhadap ekstrak $P$. varicosa dan ekstrak bakteri simbionnya. Hasil akhir dari penelitian ini yaitu didapatkan 5 isolat bakteri. Hasil uji aktivitas antibakteri yaitu isolat PhVa 1.1, PhVa 1.3, PhVa 2.1, PhVa 2.3 dan PhVa 2.4 memiliki aktivitas antibakteri terhadap bakteri E. coli DSM498 dan B. megaterium
\end{abstract}


DSM32 $^{\top}$. Hasil uji anti-UV menunjukkan serapan pada UV-A dengan nilai tertinggi 1,991 pada $\lambda$ $340 \mathrm{~nm}$.

Kata kunci: Nudibranchia, Phyllidia varicosa, Antibakteri, Anti-UV, Escherichia coli, Bacillus megaterium

\section{PENDAHULUAN}

Indonesia mempunyai wilayah pesisir dan lautan yang luas. Lingkungan laut berperan sangat penting dalam kehidupan manusia bukan hanya sebagai sarana sumber bahan makanan, transportasi dan wisata, tetapi juga merupakan habitat dari berbagai bagai biota yang bermanfaat. Keanekaragaman hayati yang sangat tinggi serta factor-faktor lingkungan di laut yang juga beragam membuat sumber daya alam laut menarik diteliti untuk mendapatkan produk alami. Sumber daya alam laut merupakan sumber daya hayati yang potensial untuk dikembangkan dan dikelola secara maksimal (Marzuki dkk., 2018). Salah satu organisme laut yang diteliti belakangan ini yaitu kelinci laut atau lebih dikenal sebagai Nudibranchia. Menurut Fisch dkk (2017) Nudibranchia dapat menghasilkan penemuan produk alami yang menarik secara farmakologis.

Salah satu organisme laut dari subkelas Heterobranchia telah diteliti secara luas termasuk potensi farmasetika mereka yaitu spesies Aplysia californica dari ordo Aplysiida. Organisme ini merupakan contoh menarik dalam penelitian neurobiologis, yang melibatkan tingkah laku organisme ini dalam mencari makan dan mekanisme pertahanan diri mereka. Senyawa yang dihasilkan Nudibranchia walaupun dalam konsentrasi rendah namun dapat digunakan sebagai senjata kimia (Pawlik dkk., 1988).

Di samping kamuflase, Nudibranchia sebagian besar menggunakan senyawa kimia untuk sistem pertahan diri. Senyawa-senyawa ini diperoleh dari pakan alami organisme ini (Cheney dkk., 2016) beberapa penelitian memperlihatkan bahwa Nudibranchia, dari spesies Phyllodesmium, menggunakan keanekaragaman kimiawi bersumber dari makanan sebagai mekanisme pertahanan diri melawan predasi dan infeksi pathogen lainnya (Fisch dkk., 2017). Bahan alam berupa senyawasenyawa kimia tersebut berpotensi dikembangkan sebagai bahan obat (Dahuri, 2003).

Terjadinya perubahan iklim yang sangat signifikan, yang diakibatkan oleh pemanasan global, dapat mengakibatkan penipisan lapisan ozon. Bila lapisan ozon ini semakin menipis, dapat mengakibatkan berbagai penyakit, salah satunya adalah kanker kulit (Warouw dan Losung, 2015). Beberapa organisme laut ditemukan memiliki senyawa organik yang bersifat sebagai anti-UV yaitu Mycosporine-like amino acids (MAAs) (Dunlap \& Shick, 1998).

\section{METODE PENELITIAN}

Waktu dan Tempat Penelitian

Pada penelitian ini pengambilan sampel diambil dari perairan Tanjung 
Mandolang, Kec. Mandolang Kabupaten Minahasa, Sulawesi Utara. Pengambilan sampel dilakukan pada siang hari dengan cara menyelam dengan menggunakan 1 set alat selam pada kedalaman \pm 15 meter, sampel diambil langsung dari substratnya dengan kondisi perairan saaat itu sedang surut dan cuaca cerah. Sampel yang telah didapat kemudian dimasukkan ke dalam botol sampel bersih dan dibawa ke daratan untuk diidentifikasi.
Pengidentifikasi sampel Nudibranchia dilakukan dengan mengamati bentuk morfologi tubuh mulai dari bentuk, warna, dan tekstur Nudibranchia. Identifikasian dilakukan dengan dipandu buku "Nudibranchia \& Sea Slug Identification" (Gosliner dkk, 2018).
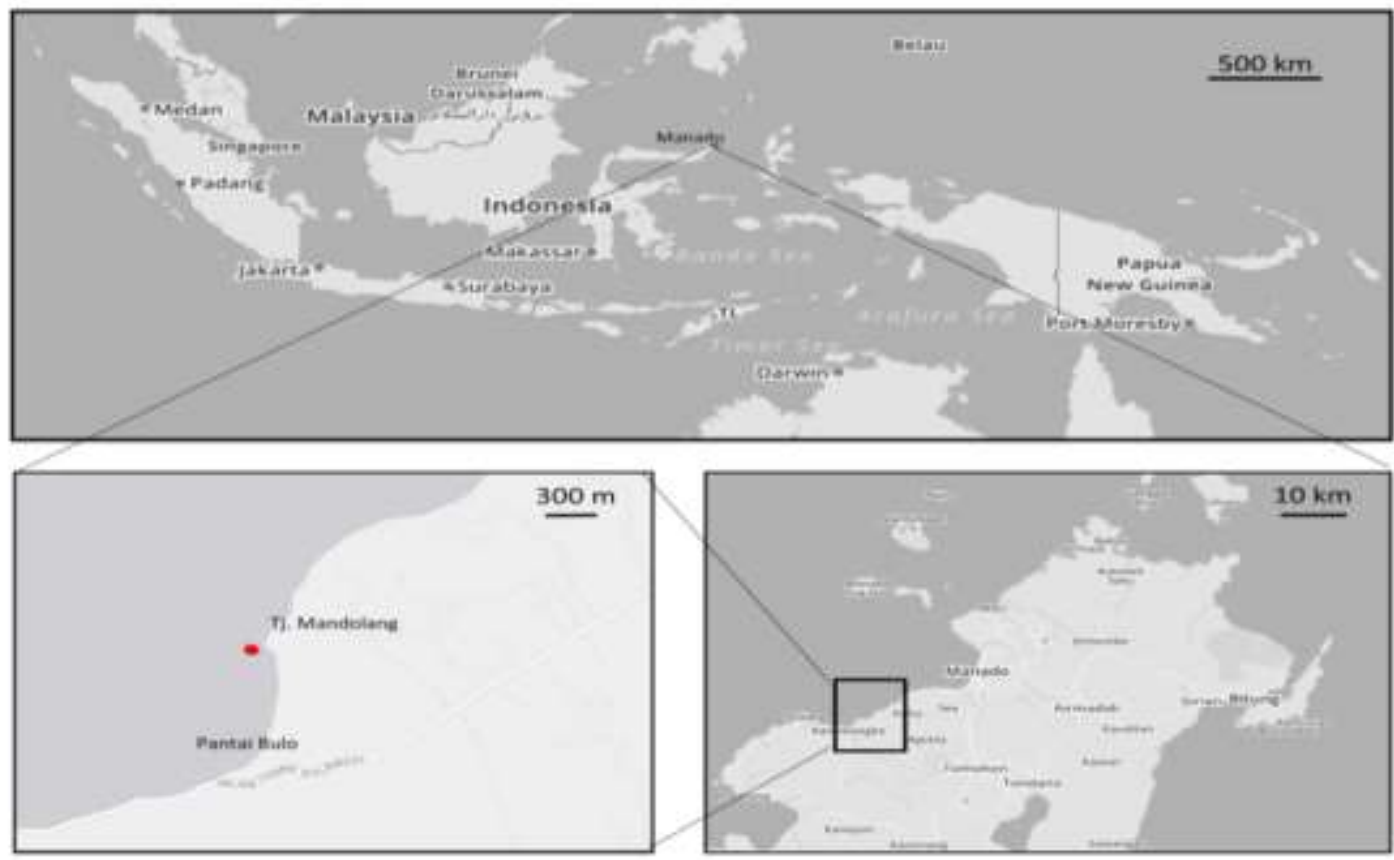

Gambar 1. Peta lokasi pengambilan sampel (National Geography Mapmaker)

\section{Pengambilan dan Penangan Sampel}

Sampel diambil menggunakan pinset dan dicelupkan kedalam etanol 96\% selama 3 detik, diangkat lalu dipotong bagian tubuh $\pm 1 \mathrm{~cm}$ dan dimasukkan ke eppendorf yang telah berisi media Marine broth kemudian akan diinkubasi selama 2×24 jam. Bagian tubuh lainnya dari sampel dimasukkan ke dalam botol sampel dan dimasukkan etanol 96\%. Sampel selanjutnya dibawa ke Laboratorium Biologi Molekuler dan Farmasetika Laut Fakultas Perikanan dan IImu Kelautan UNSRAT untuk penelitian lebih lanjut.

\section{Isolasi Bakteri Phyllidia varicosa}

Isolasi sampel $P$. varicosa dilakukan dengan di tanam pada media padat Nutrient agar. Media MB (Marine broth) yang berisi sampel diambil 
sebanyak $100 \mu \mathrm{l}$ menggunakan mikropipet lalu di totolkan pada media NA kemudian digores membentuk zig zag menggunakan jarum ose steril dan diinkubasi selama 1x24 jam.

\section{Kultur Bakteri (Streak Plate Method)}

Bakteri yang telah tumbuh pada

media Nutrient agar selama 1 hari dilanjutkan pemurnian dengan metode streak plate. Gores bakteri dengan jarum ose pada permukaan cawan petri yang berisi media padat Nutrient agar dan membentuk zig zag, inkubasi selama 1x24 jam. Metode gores akan dilakukan berulang-ulang sampai diperoleh koloni terpisah.

\section{Kultur Bakteri Biakan Murni}

Bakteri biakan murni dikultur pada media cair Brain Heart Infusion sebanyak 5 erlenmeyer untuk kultur 5 isolat bakteri. Banyaknya bahan untuk tiap erlenmeyer yaitu 3,7 gram untuk 100 $\mathrm{ml}$ media. Lalu, tambahkan akuades sebanyak $100 \mathrm{ml}$ dan aduk secKemudian tutup permukaan erlenmeyer menggunakan alumunium foil. Sterilkan seluruh media dalam erlenmeyer tersebut dengan menggunakan autoklaf selama \pm 20 menit, dan dinginkan pada suhu ruangan.

Bakteri biakan murni pada media padat Nutrient agar diambil dengan menggunakan jarum ose kemudian di masukkan kedalam erlenmeyer yang telah berisi media $\mathrm{BHI}$, inkubasi bakteri selama 2x24 jam pada suhu ruangan dan goyangkan pada shaker berkecepatan 100rpm.

\section{Ekstraksi Kultur Bakteri Simbion Phyllidia varicosa}

Bakteri yang telah dikultur pada media BHI sebanyak $100 \mathrm{ml}$ pada erlenmyer $250 \mathrm{ml}$ kemudian akan dimaserasi menggunakan etil asetat 100 ml. Bakteri dan etil asetat yang telah dimasukkan dalam satu wadah erlenmeyer kemudian dimaserasi selama $1 \times 24$ jam.

Selanjutnya sampel yang telah dimaserasi selama 1 hari dipisahkan antara fraksi air dan fraksi etil menggunakan labu pisah. Dimasukkan media kedalam labu pisah kemudian dikocok-kocok secara horizontal hingga tercampur media BHI dan etil asetat. Setelah itu didiamkan sekitar 5 menit sampai terbentuk dua lapisan. Lapisan bagian bawah yaitu fraksi air dibuang. Setelah itu lapisan atas yaitu etil asetat dievaporasi dengan menggunakan rotary vacuum evaporator pada suhu $40^{\circ} \mathrm{C}$ hingga diperoleh ekstrak. Ektrak tersebut kemudian dipindahkan kebotol sampel kecil. Selanjutnya kelima ekstrak ditimbang menggunakan timbangan analitik.

\section{Ekstraksi Phyllidia varicosa}

Sebagian tubuh dari sampel Phyllidia varicosa yang tidak dimasukkan ke media MB (Marine Broth) dimaserasi dalam larutan etanol $96 \%$ kemudian dimasukkan ke dalam botol sampel.

\section{Pembuatan Kontrol}

Kontrol positif dibuat dari $250 \mathrm{mg}$ kloramfenikol yang dilarutkan dalam 250 $\mathrm{ml}$ aquades. Sedangkan kontrol negatif menggunakan pelarut etanol $40 \%$.

\section{Kultur Mikroorganisme Uji}

Bakteri E. coli DSM498 dan $B$. megaterium $\mathrm{DSM}^{\top}{ }^{\top}$ yang digunakan 
dalam penelitian ini diperoleh dari Deutsche Sammlung von Mikroorganismen und Zellkulturen (DSMZ), Braunschweig, Jerman. Bakteri uji diambil menggunakan mikropipet sebanyak $1 \mathrm{ml}$ dan dimasukkan kedalam masing-masing tabung reaksi berisi media NB. Setelah proses pemasukkan kedua mikroorganisme uji bakteri pada tabung reaksi selesai, kemudian diinkubasi pada suhu ruangan selama 1x24 jam.

\section{Pengujian Aktivitas Antibakteri}

Pengujian antibakteri fraksi etil asetat dari ekstrak Nudibranchia $P$. varicosa pada penelitian ini diambil $20 \mu \mathrm{l}$ menggunakan mikropipet untuk ditotolkan pada kertas cakram. Metode yang digunakan pada penelitian ini adalah difusi agar (disc diffusion Kirby and Bauer Method). Pengujian aktivitas

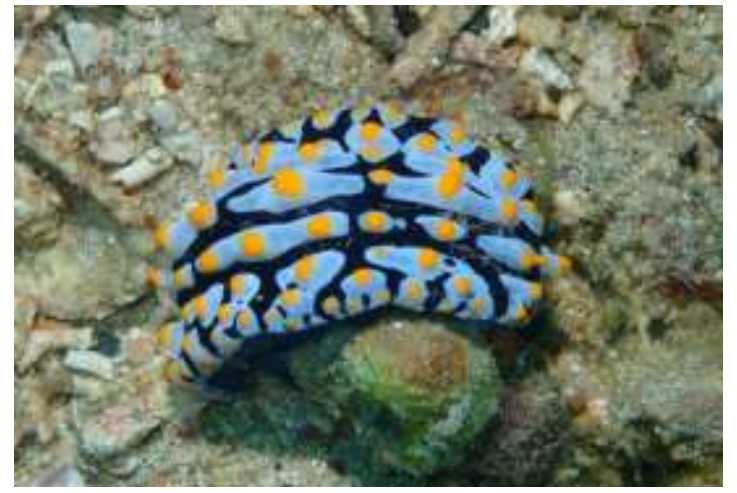

Gambar 2. Nudibranchia $P$. varicosa

Isolasi Bakteri Phyllidia varicosa

Koloni tunggal yang diperoleh pada saat tahap isolasi dan kultur

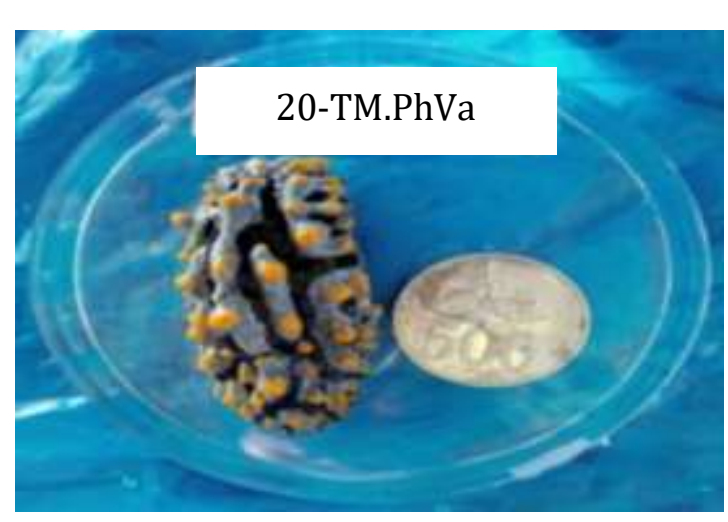

antibakteri untuk tiap bakteri dilakukan 3 kali ulangan.

\section{Pengujian Anti-UV}

Pengujian anti-UV ekstrak $P$. varicosa dan ekstrak etil asetat bakteri Nudibranchia $P$. varicosa diuji menggunakan alat spektrofotometer UVVis. Penelitian dilakukan dengan memasukkan masing-masing ekstrak kedalam suprasi kuvet sebanyak $1 \mathrm{ml}$ mengggunakan mikropipet dan diujikan pada panjang gelombang $\lambda$ 280-350 nm, selanjjtnya diamati absorbansi ekstrak tersebut.

\section{HASIL DAN PEMBAHASAN} Pengambilan dan Identifikasi Sampel

Sampel yang diperoleh dari perairan Tanjung Mandolang yaitu Nudibranchia Phyllidia varicosa (Gambar 2).

kemudian dipisahkan dan ditumbuhkan kembali pada media yang baru. 


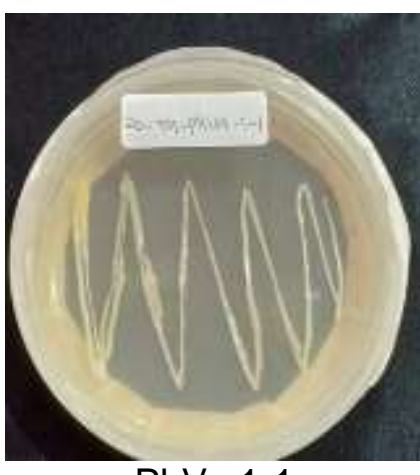

PhVa 1-1

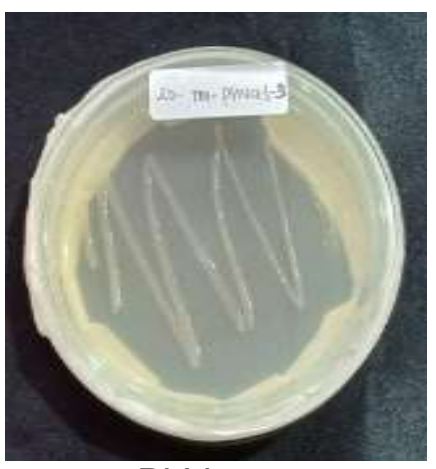

PhVa 1-3

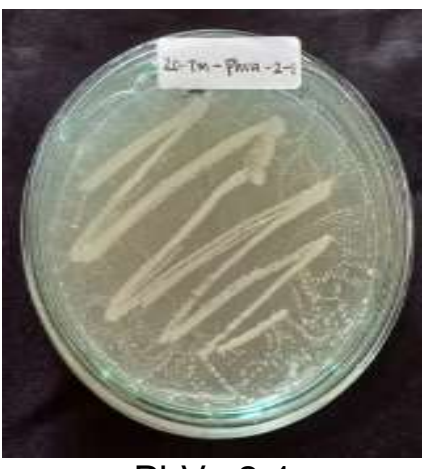

PhVa 2-1

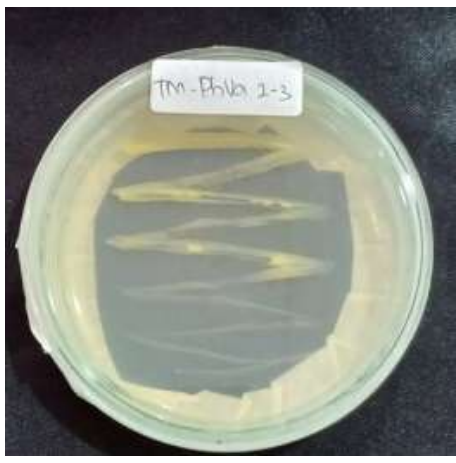

PhVa 2-3

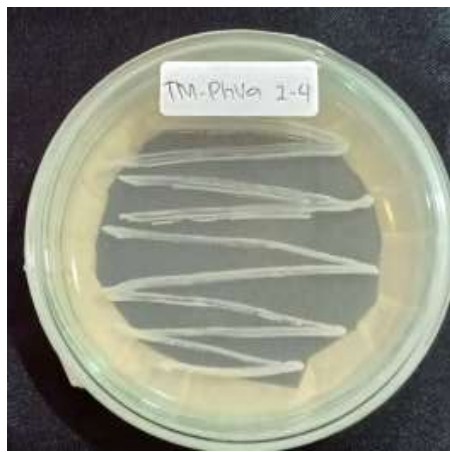

PhVa 2-4

\section{Ekstraksi Bakteri Phyllidia varicosa}

Sampel yang telah dimaserasi selama 1 hari dipisahkan antara fraksi air dan fraksi etil menggunakan labu pisah. Tabel 1. Hasil ekstraksi isolat bakteri

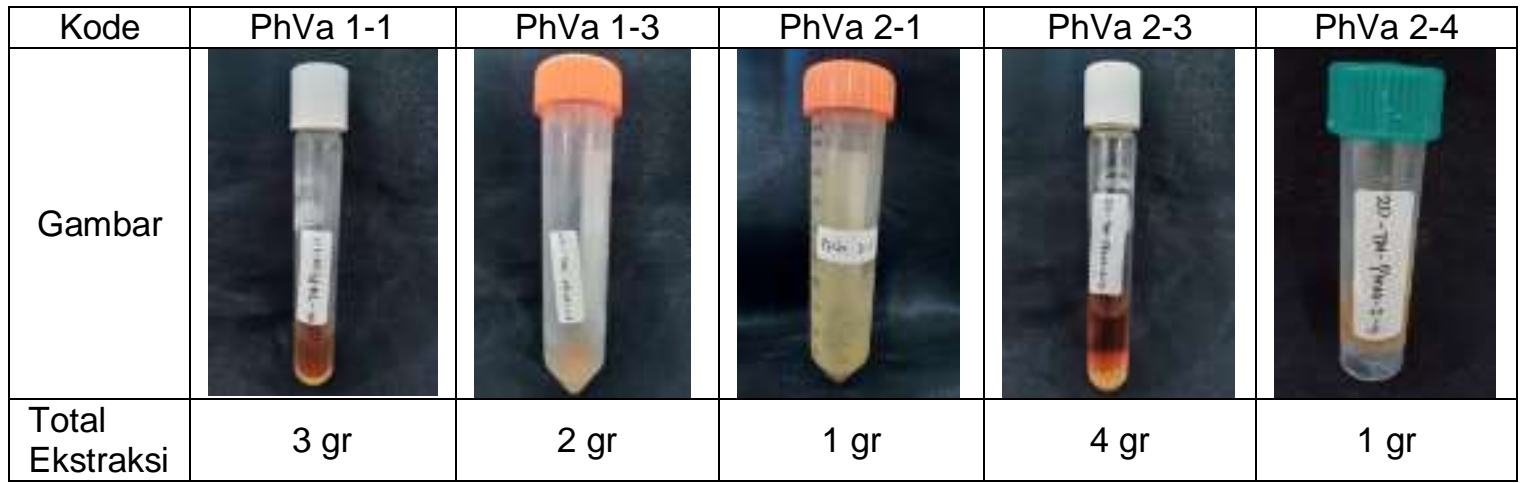

\section{Pengujian Aktivitas Antibakteri}

Aktivitas antibakteri dilihat dengan adanya zona hambat pada sekitar kertas cakram. Pengamatan dan pengukuran zona hambat menggunakan mistar dilakukan pada media mikroorganisme uji $E$. coli dan $B$.
Lapisan etil asetat yang didapat diekstraksi menggunakan alat Rotary vacuum evaporator. Hasil evaporasi ditunjukkan pada Tabel 1. 
bakteri $E$. coli dan $B$. megaterium (Gambar 3 dan Tabel 2). Pada media bakteri E. coli menunjukkan ekstrak bakteri PV 1-1 menunjukkan diameter zona hambat pada ulangan I (7 mm), ulangan II (8 mm), dan ulangan III (10 $\mathrm{mm})$. Ekstrak bakteri PV 1-3 menunjukkan diameter zona hambat pada ulangan I (8 mm), ulangan II (12 $\mathrm{mm})$, dan ulangan III (9 mm). Ekstrak bakteri PV 2-1 menunjukkan diameter zona hambat pada ulangan I (11 mm), ulangan II (0 mm), dan ulangan III (10 $\mathrm{mm})$. Ekstrak bakteri PV 2-3 menunjukkan diameter zona hambat pada ulangan I (8 mm), ulangan II (9 $\mathrm{mm})$, dan ulangan III (10 mm). Ekstrak bakteri PV 2-4 menunjukkan diameter zona hambat pada ulangan I (7 mm), ulangan II (9 mm), dan ulangan III (8 $\mathrm{mm})$. Ekstrak PhVa menunjukkan diameter zona hambat pada ulangan I (8 $\mathrm{mm})$, ulangan II (13 $\mathrm{mm})$, dan ulangan III (10 mm). Selanjutnya kontrol positif menunjukkan diameter zona hambat pada ulangan I (21 mm), ulangan II (15,5 $\mathrm{mm})$, dan ulangan III (19 mm).
Pada media bakteri $B$. megaterium menunjukkan ekstrak PV 1-1 menunjukkan diameter zona hambat pada ulangan I (8 mm), ulangan II (12 $\mathrm{mm})$, dan ulangan III (10 mm). Ekstrak PV 1-3 menunjukkan diameter zona hambat pada ulangan I (14 mm), ulangan II (15 mm), dan ulangan III (13 $\mathrm{mm})$. Ekstrak PV 2-1 menunjukkan diameter zona hambat pada ulangan I (10 mm), ulangan II (10 mm), dan ulangan III (11 mm). Ekstrak PV 2-3 menunjukkan diameter zona hambat pada ulangan I $(0 \mathrm{~mm})$, ulangan II (15 $\mathrm{mm})$, dan ulangan III (14,5 mm). Ekstrak PV 2-4 tidak menunjukkan diameter zona hambat pada ulangan I, ulangan II, maupun ulangan III. Ekstrak PhVa menunjukkan diameter zona hambat pada ulangan I (0 mm), ulangan II (12,5 $\mathrm{mm})$, dan ulangan III (13 $\mathrm{mm})$. Selanjutnya kontrol positif menunjukkan diameter zona hambat pada ulangan I (28,5 mm), ulangan II (21 mm), dan ulangan III $(21 \mathrm{~mm})$.

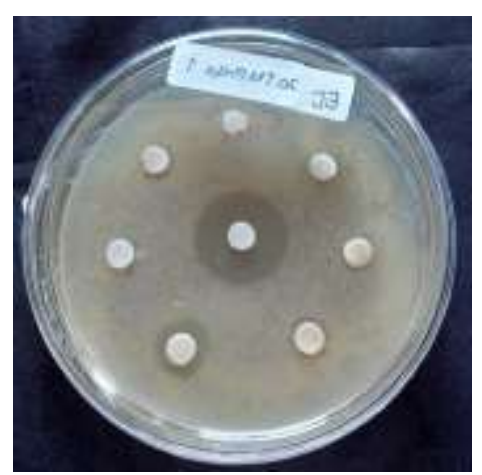

EC.1

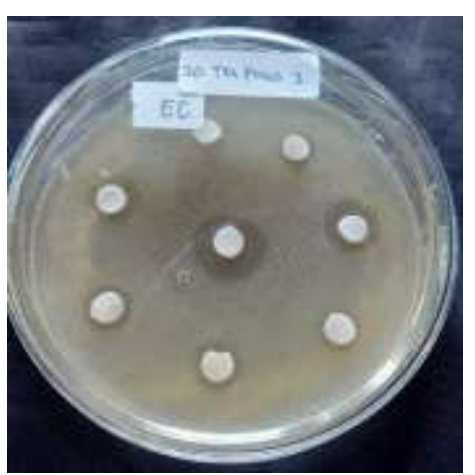

EC. 2

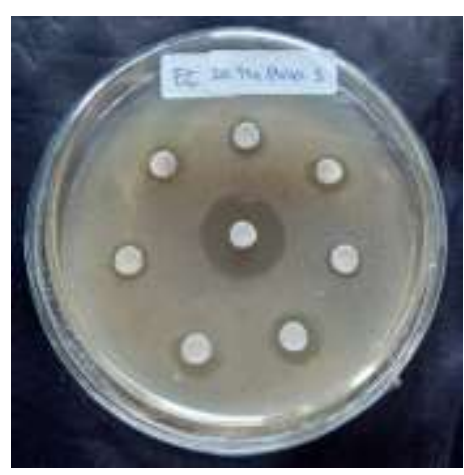

EC. 3 


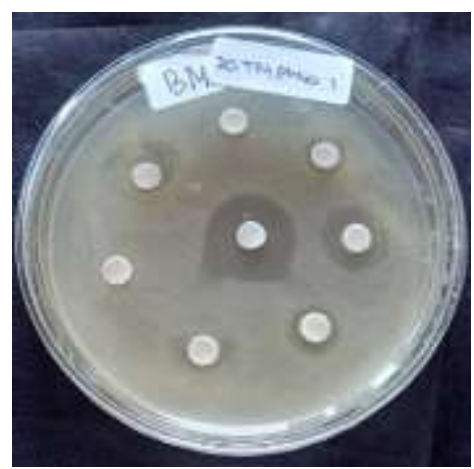

BM.1

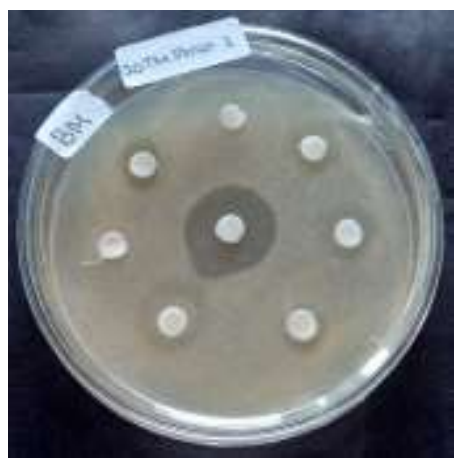

BM.2

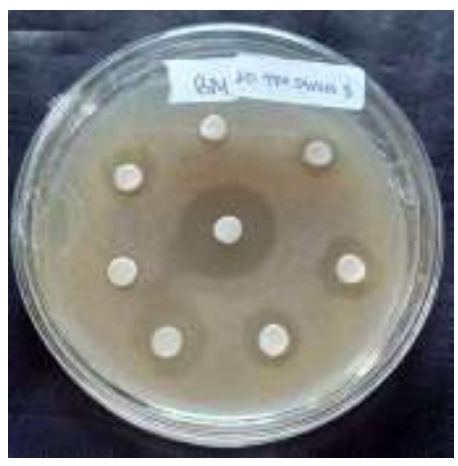

BM.3

Gambar 3. Hasil pengujian antibakteri pada media bakteri E. coli dan B. megaterium.

Table 2. Hasil uji aktivitas antibakteri dari ekstrak $P$. varicosa dan bakteri simbionnya

\begin{tabular}{|l|c|c|c|c|c|c|}
\hline \multirow{2}{*}{ Kode } & \multicolumn{7}{|c|}{ Zona Hambat (mm) } \\
\cline { 2 - 7 } & \multicolumn{7}{|c|}{ E. coli DSM498 } & \multicolumn{2}{c|}{ B. megaterium DSM32 } \\
\hline PV 1-1 & 7 & 8 & 10 & 8 & 12 & 10 \\
\hline PV 1-3 & 8 & 12 & 9 & 14 & 15 & 13 \\
\hline PV 2-1 & 11 & 0 & 10 & 10 & 10 & 11 \\
\hline PV 2-3 & 8 & 9 & 10 & 0 & 15 & 14,5 \\
\hline PV 2-4 & 7 & 9 & 8 & 0 & 0 & 0 \\
\hline PhVa & 8 & 13 & 10 & 0 & 12,5 & 13 \\
\hline Kontrol + & 21 & 15,5 & 19 & 28,5 & 21 & 21 \\
\hline Kontrol - & - & - & - & - & - & - \\
\hline
\end{tabular}

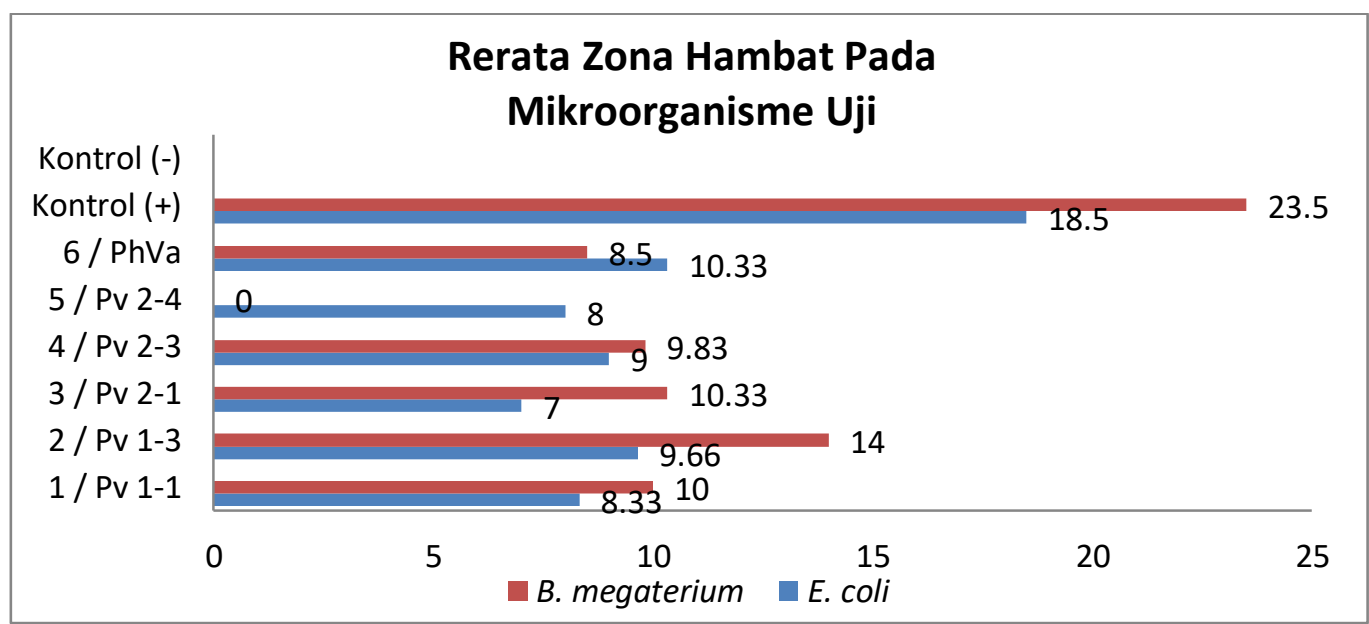

Gambar 4. Rerata zona hambat ekstrak $P$. varicosa, ekstrak etil asetat dan kontrol terhadap pertumbuhan bakteri $E$. coli dan B. megaterium.

Menurut Davis dan Stout (1971) penggolongan kriteria kekuatan suatu bahan antibakteri, yakni diameter zona hambat $5 \mathrm{~mm}$ atau kurang dikategorikan lemah, dan zona hambat 5-10 mm dikategorikan sedang, sedangkan diameter zona hambat 10-20 mm dikategorikan kuat dan diameter zona hambat melebihi dari $20 \mathrm{~mm}$ dikategorikan sangat kuat. 
Dari rerata zona hambat (Gambar 4) pada bakteri $E$. coli yang diperoleh maka diketahui ekstrak isolat 1/PV 1-1 menghasilkan rerata zona hambat sebesar 8,33 mm, ekstrak isolat 2 / PV 13 menghasilkan rerata zona hambat sebesar 9,66 mm, ekstrak isolat 3 / PV 21 menghasilkan rerata zona hambat sebesar $7 \mathrm{~mm}$, ekstrak isolat 4 / PV 2-3 menghasilkan rerata zona hambat sebesar $9 \mathrm{~mm}$, dan ekstrak isolat 5 / PV 2-4 menghasilkan rerata zona hambat sebesar $8 \mathrm{~mm}$ yang menunjukkan kelima isolat memiliki aktivitas antibakteri yang tergolong sedang. Selanjutnya untuk ekstrak isolat 6 / PhVa menghasilkan rerata zona hambat sebesar $10,33 \mathrm{~mm}$ yang menunjukkan isolat tersebut memiliki aktivitas antibakteri yang tergolong kuat.

Pada Gambar 4 rerata zona hambat bakteri $B$. megaterium diketahui ekstrak isolat 1/ PhVa 1.1 menghasilkan rerata zona hambat sebesar $10 \mathrm{~mm}$, ekstrak isolat 2 / PV 13 menghasilkan rerata zona hambat sebesar $14 \mathrm{~mm}$, dan ekstrak isolat 3 / PV 2-1 menghasilkan rerata zona hambat sebesar 10,33 mm yang menunjukkan bahwa ketiga isolat tersebut memiliki aktivitas antibakteri yang tergolong kuat. Selanjutnya ekstrak isolat 4 / PV 2-3 menghasilkan rerata zona hambat sebesar $9,83 \mathrm{~mm}$ dan ekstrak isolat 6 / PhVa menghasilkan penghambatan sebesar $8,5 \mathrm{~mm}$ yang menunjukkan kedua isolat memiliki aktivitas antibakteri yang tergolong sedang. Sedangkan ekstrak isolat 5 / P.V 2-4 tidak menghasilkan rerata zona hambat karena tidak memiliki aktivitas zona hambat.
Pada penelitian yang dilakukan tampak bahwa kontrol positif kloramfenikol jauh lebih efisien untuk menghambat pertumbuhan bakteri uji yaitu pada bakteri $E$. coli rerata zona hambatnya sebesar $(18,5 \mathrm{~mm})$ dan pada bakteri $B$. megaterium menghasilkan rerata zona hambat sebesar $(23,5 \mathrm{~mm})$. Faktor yang mempengaruhi hal di atas karena Minimum Inhibitory Concentration (MIC), kloramfenikol telah diketahui kosentrasi yang paling tepat untuk menghambat aktivitas pertumbuhan bakteri (Opa dkk., 2018).

Kontrol negatif yang dalam penelitian ini etanol 95\% yang digunakan untuk melarutkanekstrak dari sampel uji. Kontrol negatif menunjukkan tidak adanya zona hambat pada pengujian antibakteri terhadap bakteri $E$. coli dan $B$. megaterium. Hal ini mengindikasikan bahwa kontrol negatif yang digunakan tidak berpengaruh pada uji bioaktivitas antibakteri sampel, sehingga daya hambat yang terbentuk tidak dipengaruhi oleh pelarut melainkan karena aktivitas senyawa aktif yang terdapat pada nudibranch $P$. varicosa (Opa dkk., 2018).

Senyawa antibakteri dapat digolongkan juga sebagai spektrum luas dan spektrum sempit. Spektrum luas artinya senyawa tersebut bekerja aktif terhadap banyak jenis bakteri baik bakteri Gram positif dan bakteri Gram negatif. Sedangkan spektrum sempit artinya suatu senyawa bekerja aktif hanya terhadap satu golongan bakteri saja baik hanya pada bakteri Gram positif ataupun hanya pada bakteri Gram negatif (WHO, 2014). Dari hasil penelitian menunjukkan bahwa senyawa antibakteri yang terdapat pada ekstrak 
etil asetat bakteri simbion Phyllidia varicosa termasuk berspektrum luas dikarenakan memiliki kemampuan menghambat bakteri Gram positif dan bakteri Gram negatif.

Sebagian Nudibranchia memproduksi racun sendiri, namun umumnya mengambil dari mangsa, sebagian besar juga menggunakan senyawa kimia untuk sistem pertahan diri, yang diproduksi dari pakan alami organisme ini (Cheney dkk., 2016). Penelitian dari Fisch dkk (2017) memperlihatkan organisme $P$. varicosa memiliki aktivitas terhadap antifeedant terhadap beberapa jenis ikan dan penelitian awal dilaporkan sekresi dari $P$. varicosa bersifat lethal pada beberapa spesies ikan dan krustasea penelitian lanjut dari organisme ini mengandung isosianida sesquiterpen trisiklik (RitsonWilliams dan Paul, 2007) Selanjutnya $P$. varicosa yang dikoleksi dari Perairan Sri Lanka diperoleh senyawa bisabolen isosianotheonellin tipe-3. Senyawa ini memiliki aktivitas antifouling yang potent (Gulavita dkk., 1986). P. varicosa juga mampu mengambil bahan kimia yang ditemukan di spons yang dimakannya dan mengubahnya menjadi zat beracun yang melindunginya dari pemangsaan dari hewan lain. Nudibranch yang tidak memiliki cangkang ini mampu mensintesis metabolit sekunder dari bahan makananya (Karunasagar dan Reilly, 1999). Penelitian dari Boehringer dkk (2017), memperlihatkan beberapa bakteri simbion dari beberapa Nudibranchia yang dikoleksi dari Perairan Bunaken memiliki kandungan gen-gen penyandi kompleks enzim Polyketide Synthase (PKS). Penyandian gen PKS ini ditengarai menghasilkan metabolit sekunder yang memiliki aktivitas biologis beragam yang potent (Holger dkk, 2005, Koehn dan Carter, 2005).

\section{Pengujian Anti-UV}

Penentuan efektivitas anti UV-A dan anti UV-B dilakukan dengan penentuan nilai SPF menggunakan alat spektrofotometer UV/Vis pada panjang gelombang 280 sampai $350 \mathrm{~nm}$. Nilai SPF sampel $P$. varicosa disajikan pada Gambar 17.

Pengujian anti-UV yang diujikan pada ekstrak bakteri isolat 1 / PhVa 1.1, ekstrak bakteri isolat 2 / 1.3, ekstrak bakteri isolat 4 / 2.3 dan ekstrak $P$. varicosa untuk melihat serapan pada $\lambda$ 280-350 nm. Pada pengujian ini ekstrak $P$. varicosa menunjukkan serapan maksimum UV pada $\lambda 340 \mathrm{~nm}$ dengan nilai absorbansi $1.991 \mathrm{mAU}$ dan $\lambda 350 \mathrm{~nm}$ dengan nilai absrobansi 1,653 mAU, grafik absorbansi UV ekstrak P. varicosa tersaji pada Gambar 17. Selanjutnya ekstrak ketiga bakteri simbion $P$. varicosa tidak menunjukkan nilai serapan UV-A maupun UV-B pada range panjang gelombang $\lambda$ 280$350 \mathrm{~nm}$, mengindikasikan tidak adanya senyawa anti-UV yang dimiliki ketiga bakteri simbion tersebut. 


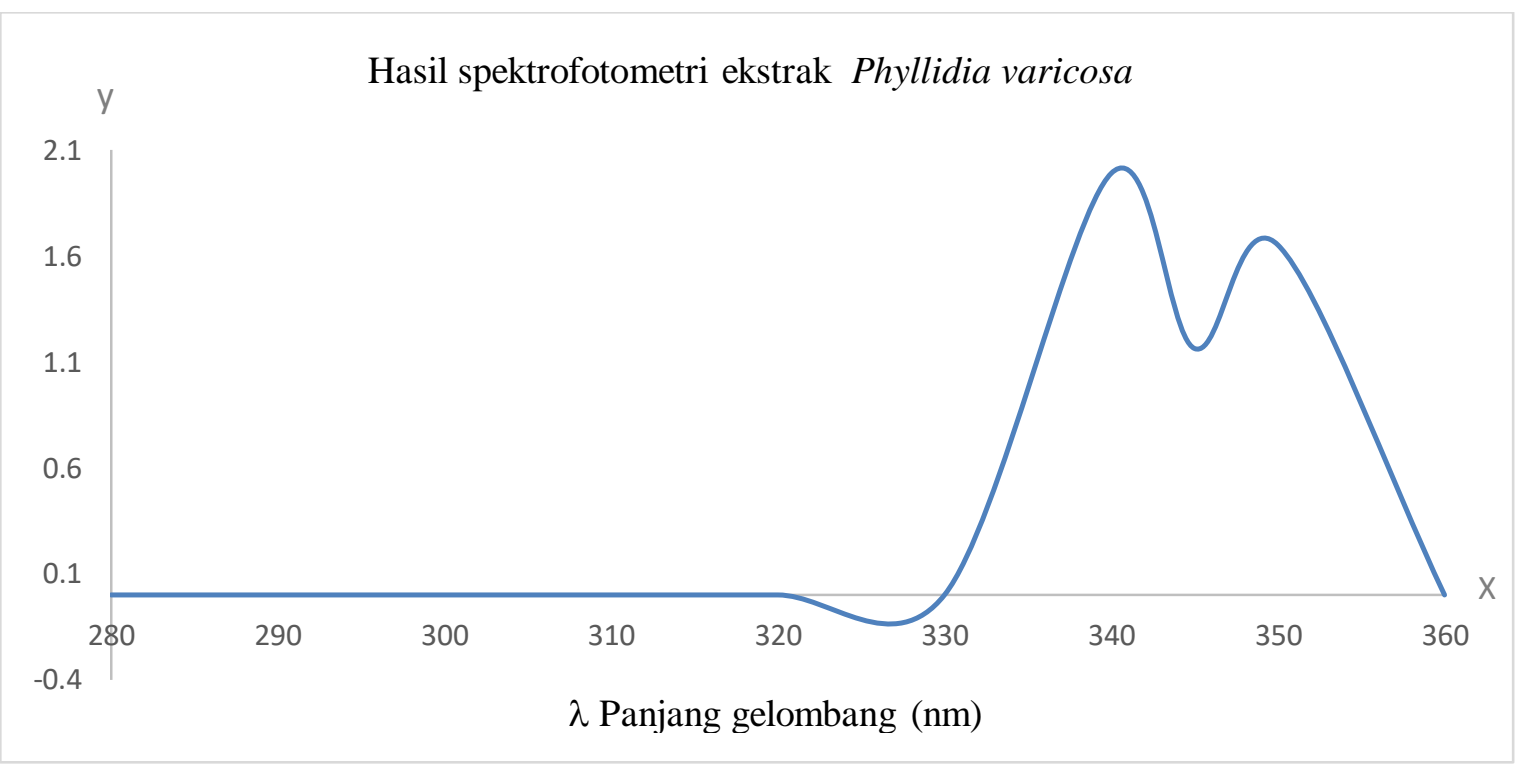

Gambar 5. Hasil spektrofotometri ekstrak $P$. varicosa

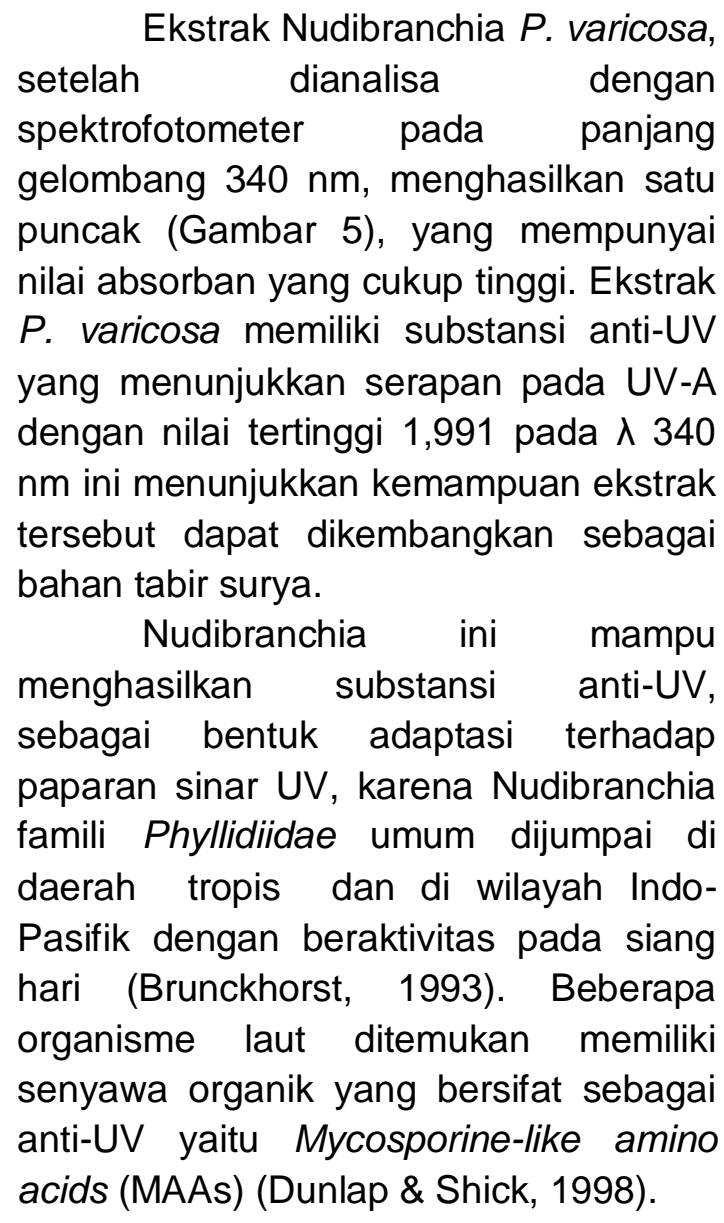

\section{KESIMPULAN}

Berdasarkan hasil penelitian yang dilakukan, maka dapat disimpulkan bahwa:

1. Telah diisolasi 5 isolat bakteri yang bersimbiosis dengan Nudibranchia $P$. varicosa.

2. Dari hasil pengujian antibakteri yang telah dilakukan, ekstrak $P$. varicosa dan ekstrak isolat $\mathrm{PhVa}$ 1.1, PhVa 1.3, PhVa 2.1, PhVa 2.3 dan PhVa 2.4., memiliki aktivitas antibakteri terhadap bakteri $E$. coli DSM498 dan bakteri B. megaterium DSM32 ${ }^{\top}$.

3. Pengujian anti-UV yang dilakukan menunjukkan bahwa ekstrak $P$. varicosa menunjukkan serapan pada UV-A dengan dua puncak UV pada panjang gelombang $\lambda$ $340 \mathrm{~nm}$ dan pada $\lambda 350 \mathrm{~nm}$. Ekstrak bakteri simbion $P$. varicosa tidak memperlihatkan serapan UV pada range panjang gelombang $\lambda$ 280-350 $\mathrm{nm}$. 


\section{DAFTAR PUSTAKA}

Boehringer, N., K. M. Fisch, D. Schillo, R. Bara, C. Hertzer, F. Grein, J.$H$. Eisenbarth, F. Kaligis, T. Schneider, H. Waegele, G. M. Koenig and T. F. Schaeberle. 2017. Antimicrobial Potential of Bacteria Associated with Marine Sea Slugs from North Sulawesi, Indonesia. Frontiers in Microbiology 8: 1092.

Brunckhorst, J. D. 1993. The Systematics and Phylogeny of Phyllidiid Nudibranchs (Doridoidea). Records of the Australian Museum Supplement 1.

Cheney, K. L., White, Andrew., Mudianta, I. Wayan., Winters, A. E., Quezada, Michelle., Capon, R. J., Mollo, Ernesto., Garson, M, J. 2016. Choose Your Weaponry: Selective Storage of a Single Toxic Compound, Latrunculin A, by Closely Related Nudibranch Molluscs.

Dahuri, R. 2003. Keanekaragaman Hayati Laut: Aset Pembangunan Berkelanjutan Indonesia. Gramedia Pustaka Utama. Jakarta.

Davis, W. W., T. R. Stout. 1971. Disc plate methods of microbiological antibiotic assay. Microbiology 22: 659-665.

Fisch, K. M., Hertzer C ., Boehringer, N., , Wuisan Z. G., Schillo, D., Bara R., Kaligis, F., Wagele, H., Konig, G. M.., dan Schaeberle, T. F. 2017. The Potential of Indonesian Heterobranchs Found around Bunaken Island for the Production of Bioactive
Compounds. Journal of Marine Drugs. 39 hal.

Gulavita, N. K., De Silva, E. D., Hagadone, M. R., Karuso, P., Scheuer, P. J., Van Duyne, G. D., Clardy, J. 1986. Nitrogenous bisabolene sesquiterpenes from marine invertebrates. Journal of Organic Chemistry. Vol. 51. Hal. 5136-5139.

Gosliner, T. M., Valdes, A., Behrens, D. W. 2018. Nudibranch \& Sea Slug Identification - Indo-Pacific $-2^{\text {nd }}$ Edition

Holger, J. K., Sandmann, A., Müller, R., Dittmann, E. 2005. Evolutionary Implications of Bacterial Polyketide Synthases, Molecular Biology and Evolution, Vol. 22. Hal. 2027-2039, https://doi.org/10.1093/molbev/msi 193

Karunasagar, Iddya., Karunasagar, I., dan Reilly, A. 1999. Aquaculture and Biotechnology

Koehn, F., Carter, G. 2005. The evolving role of natural products in drug discovery. Nature Reviews Drug Discovery Vol. 4. Hal. 206-220. https://doi.org/10.1038/nrd1657.

Marzuki, I., Noor A., Nafie N. L., dan Djide N. M. 2018. Isolasi dan Identifikasi Bakteri Simbion Spons Penghasil Enzim Amilase Asal Pantai Melawai Balikpapan. Jurnal Ilmiah "dr. Aloei Saboe". Vol 1 No. 2.Hal.11-12.

National Geographic Mapmaker https://mapmaker.nationalgeograph ic.org

Opa, S. L., Bara, R. A., Gerung G. S., Rompas, R. M. Lintang, R. A. J., Sumilat, D. A. 2018. Uji Aktivitas 
Antibakteri Fraksi N-Heksana, Metanol Dan Air Dari Ascidian Lissoclinum sp. Jurnal Pesisir dan Laut Tropis. Vol. 1.No. 1.Hal.6980.

Pawlik, J. R., Kernan. M. R., Molinski. T. F., Harper. M. K., Faulkner. D. J. 1988. Defensive Chemicals of the Spanish Dancer Nudibranch Hexabranchus sanguineus and Its Egg Ribbons : Macrolides Derived From a Sponge Diet. J. Exp. Mar. Biol. Ecol., Vol. 119 (99-109).

Ritson-Williams, R., Paul, V. J. 2007. Marine benthic invertebrates use multimodal cues for defense against reef fish. Marine Ecology Progress Series. 340. Hal. 29-39.

Warouw, V .dan Losung, F. 2015. Potensi Substans Anti-UV Dari Serangga Laut Family Gerridae Di Tasik Ria Mokupa Manado, Sulawesi Utara. Jurnal LPPM Bidang Sains dan Teknologi, 2(2): hal. 95-102

WHO. 2014. Antmicrobial resistance: global report on survaillance 2014. World Health Organization.p 257. 